\title{
Somatostatin analogues in acromegaly and gastroenteropancreatic neuroendocrine tumours: past, present and future
}

\author{
Kjell Öberg' and Steven W J Lamberts ${ }^{2}$ \\ 1University Hospital, Uppsala, Sweden \\ 2Erasmus Medical Center, Rotterdam, The Netherlands
}

Correspondence should be addressed to $\mathrm{K}$ Öberg Email

kjell.oberg@medsci.uu.se

\begin{abstract}
Acromegaly is a hormonal disorder that arises when the pituitary gland secretes excess growth hormone $(\mathrm{GH})$, which in turn stimulates a concomitant increase in serum insulin-like growth factor 1 (IGF-1) levels. Gastroenteropancreatic neuroendocrine tumours (GEP-NET) constitute a heterogeneous group of tumours that can secrete serotonin and a variety of peptide hormones that may cause characteristic symptoms known as carcinoid syndrome or other symptoms and hormonal hypersecretion syndromes depending on the tumour's site of origin. Current medical therapy for the treatment of acromegaly and GEP-NET involves the administration of somatostatin analogues that effectively suppress excess hormone secretion. After its discovery in 1979, octreotide became the first synthetic biologically stable somatostatin analogue with a short-acting formulation of octreotide introduced into clinical practice in the late 1980s. Lanreotide, another somatostatin analogue, became available in the mid-1990s initially as a prolonged-release formulation administered every 10 or 14 days. Long-acting release formulations of both octreotide (Sandostatin LAR and Novartis) and lanreotide (Somatuline Autogel, Ipsen), based on microparticle and nanoparticle drug-delivery technologies, respectively, were later developed, which allowed for once-monthly administration and improved convenience. First-generation somatostatin analogues remain one of the cornerstones of medical therapy in the management of pituitary and GEP-NET hormone hypersecretion, with octreotide having the longest established efficacy and safety profile of the somatostatin analogue class. More recently, pasireotide (Signifor), a next-generation multireceptor-targeted somatostatin analogue, has emerged as an alternative therapeutic option for the treatment of acromegaly. This review summarizes the development and clinical success of somatostatin analogues.
\end{abstract}

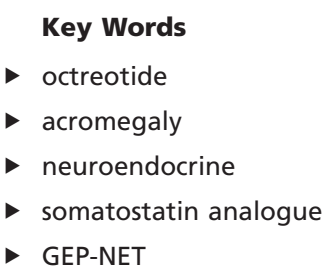

Endocrine-Related Cancer (2016) 23, R551-R566 (c) 2016 Society for Endocrinology Printed in Great Britain
Published by Bioscientifica Ltd. 


\section{Introduction}

Somatostatin analogues are the current mainstay treatment for acromegaly and gastroenteropancreatic neuroendocrine tumours (GEP-NET).

\section{Acromegaly: background}

Acromegaly is a chronic metabolic disorder with an estimated prevalence of 40-125 cases per million and an annual incidence of three to four new patients per million (Katznelson et al. 2011). It affects both genders equally and generally develops between the fourth and fifth decades of life, although it may occur at any age (Katznelson et al. 2011). In most cases, acromegaly is caused by the presence of a benign tumour in the pituitary gland (Sanno et al. 2003), which secretes excess growth hormone $(\mathrm{GH})$ with a concomitant increase in insulin-like growth factor 1 (IGF-1) by the liver, resulting in a proliferation of bone, cartilage and soft tissue. As the onset of physical changes is insidious, diagnosis can be delayed for up to 10 years in some patients (Rajasoorya et al. 1994), leading to potentially serious deleterious consequences for the patient's health and well-being. Most patients typically present at advanced stages with enlargement of the extremities and modification of facial features (Drange et al. 2000). Prolonged hypersecretion of $\mathrm{GH}$ and IGF-1 results in multiple significant co-morbidities, including cardiovascular complications (Powlson \& Gurnell 2016), impaired glucose tolerance and diabetes (Biering et al. 2000, Kasayama et al. 2000), hypertension (Lombardi et al. 2006), respiratory conditions (Attal \& Chanson 2010, Powlson \& Gurnell 2016) and colorectal neoplasms (Rokkas et al. 2008). Symptoms related to these co-morbidities are the most likely reason for undiagnosed patients with acromegaly to seek medical attention (Katznelson et al. 2011). Mortality rate is increased in acromegaly, with standardized mortality ratios relative to the general population ranging from 1.3 to 1.9 (Dekkers et al. 2008, Ritvonen et al. 2015, Dal et al. 2016), which is further elevated if co-morbidities, particularly cardiovascular disease, are present (Sherlock et al. 2010). The clinical burden of acromegaly is further compounded by the substantial impairment in quality of life (QoL) (Rowles et al. 2005, Trepp et al. 2005, T'Sjoen et al. 2007). Additionally, patients with acromegaly may experience neurocognitive (Leon-Carrion et al. 2010, Martin-Rodriguez et al. 2013) and neuropsychiatric dysfunctions (Sievers et al. 2009a,b).
Prompt diagnosis and treatment are critical as longer duration of untreated or uncontrolled acromegaly is associated with more severe complications (MartinRodriguez et al. 2013). Indeed, in some patients, cognitive (Martin-Rodriguez et al. 2013) and psychosocial (Biermasz et al. 2004, van der Klaauw et al. 2008) impairment may be irreversible. Despite the urgency to diagnose and treat, many patients with acromegaly still have uncontrolled disease, and there may be many more undiagnosed (Katznelson et al. 2011).

\section{GEP-NET: background}

GEP-NETs are relatively rare neoplasms that may present with a diverse range of functional and behavioural characteristics (Oberg 2005). Endocrine tumours of the gastrointestinal tract have historically been classified as carcinoids of the foregut, midgut and hindgut, depending on anatomical origin, with midgut carcinoids constituting the largest group of GEP-NET (Robertson et al. 2006). The World Health Organization (WHO) uses different classifications that include well-differentiated and poorly differentiated GEP-NET. The former category of tumour is relatively slow growing, whereas the latter may present as a more aggressive malignancy (Solcia et al. 2000). Non-functioning endocrine tumours do not secrete measurable amounts of biologically active hormones; in contrast, hormone hypersecretion from functioning GEP-NET is responsible for causing distinct clinical syndromes. Carcinoid syndrome is characterized by a set of symptoms that include mild-to-severe diarrhoea, flushing of the face and wheezing attacks. Despite a dearth of curative treatment options for patients with GEP-NET, QoL for these patients has dramatically improved since the introduction of somatostatin analogue therapy, which effectively alleviates symptoms and potentially inhibits tumour progression.

This article summarizes the literature regarding the development and clinical impact of the first-generation somatostatin analogues octreotide and lanreotide, and introduces pasireotide as a next-generation somatostatin analogue, in the treatment of acromegaly and GEP-NET.

\section{Clinical development}

Originally discovered as an inhibitor of $\mathrm{GH}$ release (Brazeau et al. 1973), somatostatin is a peptide hormone that plays an inhibitory role in the regulation of multiple physiological functions, including pituitary, pancreatic and gastrointestinal hormone secretion.

Published by Bioscientifica Ltd 
Somatostatin exerts its biological effects by interaction with specific somatostatin receptors (SSTR) expressed on target tissues. Five human receptor subtypes have been recognized (SSTR1-5), each mediating a distinct signalling pathway (Patel 1999). GH-secreting pituitary tumours predominantly express SSTR2 and SSTR5 (Melmed 2006), whereas SSTR2 predominates in endocrine pancreatic tumours and carcinoids (de Herder et al. 2003).

Given its role in inhibiting such a diverse array of physiological processes, therapeutic exploitation of somatostatin for the treatment of endocrine-related disorders was quickly explored but ultimately abandoned because of its rapid degradation in human plasma. Octreotide was the first biologically stable somatostatin analogue to be synthesized (Fig. 1) that exhibited a longer half-life than native somatostatin $(1.5-1.9 \mathrm{~h}$ vs $3 \mathrm{~min})$ (Bauer et al. 1982), binding with high, low and moderate affinity to SSTR2, SSTR3 and SSTR5, respectively (Hofland \& Lamberts 2003). It is also a more potent inhibitor of $\mathrm{GH}$ and insulin than somatostatin (Bauer et al. 1982). In patients with acromegaly, octreotide induced long-acting suppression of GH secretion without the rebound hypersecretion observed after somatostatin infusion (Lamberts et al. 1985a).

A short-acting immediate-release (IR) formulation of octreotide, administered either subcutaneously or intravenously, initially received regulatory approval for the treatment of acromegaly in Europe in 1988 (Fig. 1). Data from studies around this time (Lamberts et al. 1985b, Vance \& Harris 1991, Ezzat et al. 1992) demonstrated the efficacy of octreotide IR in reducing GH and IGF-1 levels in patients with acromegaly. A long-acting formulation (octreotide long-acting repeatable) was introduced and later approved in 1995; octreotide LAR is a depot preparation of octreotide encapsulated within microspheres composed of a biodegradable polymer and administered by monthly intramuscular injection.
After a single injection of octreotide LAR, octreotide is released in a short burst to an initial peak within $1 \mathrm{~h}$ of administration, which then progressively decays within $12 \mathrm{~h}$. A second-release phase then occurs, which exhibits sustained-release behaviour, reaching a plateau between days 14 and 42 (Lancranjan et al. 1995). Steady-state octreotide serum concentrations were reached after three injections and were 1.6-fold higher relative to plateau octreotide levels after the first injection (Lancranjan et al. 1995). In patients with acromegaly, the efficacy profile of octreotide LAR was found to be similar to that of octreotide IR, but with the added convenience of once-monthly administration (McKeage et al. 2003). Octreotide LAR is the most commonly prescribed formulation today, with octreotide IR primarily used in cases of symptom breakthrough or in perioperative situations.

Lanreotide is another metabolically stable somatostatin analogue that has demonstrated a similar binding profile to that of octreotide (Hofland \& Lamberts 2003). The original sustained-release formulation (lanreotide SR) used a microparticle-based drug-delivery system, which was later followed by lanreotide Autogel, the first available sustained-release formulation based on self-assembling nanotube technology (Fig. 1) (Pouget et al. 2010). After administration, lanreotide peptide monomers are slowly released from the ends of the nanotubes over a period of 1 month. Lanreotide Autogel is available in prefilled syringes and is administrated by deep subcutaneous (sc) injection (Caron et al. 2002). Lanreotide Autogel has a different release pattern than that of octreotide LAR and is characterized by an initially sharp increase that generally reaches peak concentration on day 1 , followed by a consistent decrease throughout the treatment period (Astruc et al. 2005).

Pasireotide is a next-generation, multireceptortargeted somatostatin analogue with high affinity for

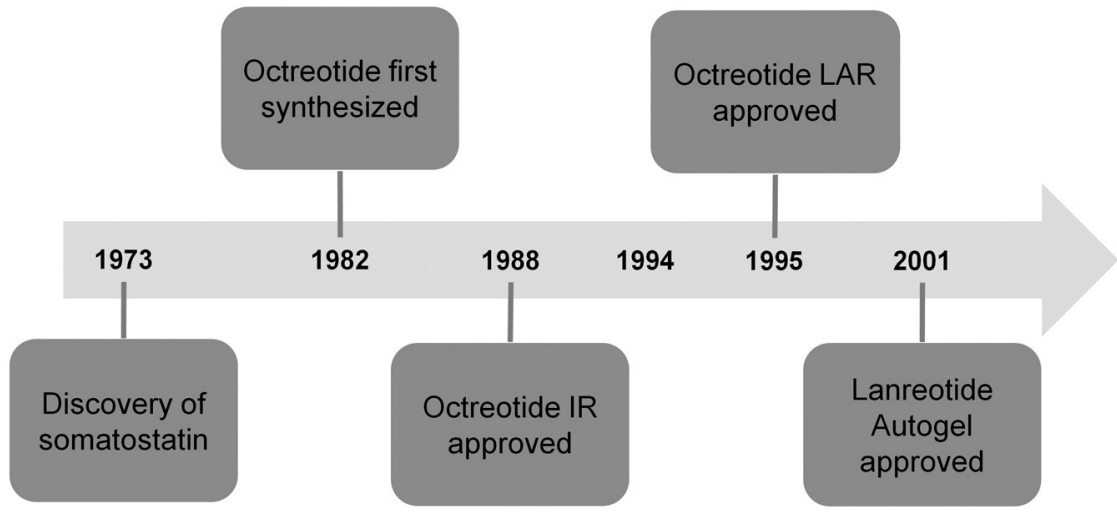

Figure 1

Development and regulatory approval timeline. Figure shows European regulatory approval for the treatment of acromegaly. 
SSTR1-3 and SSTR5 (Schmid 2008). Binding affinity to SSTR5 is 39-fold higher than that of octreotide (Schmid \& Schoeffter 2004). Two formulations of pasireotide have been developed: one for sc administration and another long-acting formulation (pasireotide LAR) for intramuscular injection (Fig. 1). Pasireotide administered subcutaneously to healthy volunteers was rapidly absorbed, with maximum plasma concentrations reached in less than $1 \mathrm{~h}$ (Petersenn et al. 2012a,b). Pasireotide LAR in healthy volunteers exhibited an extended-release profile characterized by an initial burst release, with plasma concentrations subsequently declining and then rising to a peak over approximately 1 week and 3 weeks, respectively (Dietrich et al. 2012).

\section{Clinical experience: acromegaly}

The 2014 Endocrine Society guidelines for the diagnosis and treatment of acromegaly defines a number of treatment goals: reducing circulating levels of $\mathrm{GH}$ and IGF-1, tumour volume reduction, improvement in symptoms and co-morbidities and reduction of mortality risk (Katznelson et al. 2014). Transsphenoidal surgery is the favoured approach in eligible patients, with remission rates of up to $90 \%$ and $50 \%$ in those with a microadenoma and macroadenoma, respectively (Nomikos et al. 2005, Trepp et al. 2005). Moreover, improved operative outcomes are associated with increasing neurosurgical experience (Ahmed et al. 1999, Gittoes et al. 1999). Patients with large adenomas ( $>20 \mathrm{~mm}$ ) and a GH level $>50 \mu \mathrm{g} / \mathrm{L}$ before surgery, however, are still likely to require medical therapy and possibly radiotherapy to control excess GH (Shimon et al. 2001, Nomikos et al. 2005). For patients who cannot have surgery, do not achieve remission either shortly after surgery or during long-term follow-up or experience disease recurrence after initial remission, medical therapy is indicated.

\section{Suppression of excess GH and IGF-1 levels}

Before the availability of somatostatin analogues, therapeutic options for patients with acromegaly were limited, with patients remaining uncontrolled for years (Kleinberg 2005). The introduction of octreotide in the 1980s was a quantum leap for medical therapy in acromegaly. In a meta-analysis by Freda and coworkers examining clinical trials of first-generation somatostatin analogues published before 2004, overall response rates to octreotide LAR and lanreotide SR, respectively, were 57 and $48 \%$ in terms of GH control, and 67 and $47 \%$ in terms of normalization of IGF-1 (Freda et al. 2005). These findings were corroborated by two later analyses that reported generally similar response rates for both octreotide LAR and lanreotide Autogel (Murray \& Melmed 2008, Colao et al. 2011). Together, these analyses have created the expectation that at least half of patients receiving somatostatin analogues should achieve biochemical control. However, there is considerable variation in reported biochemical response rates that is not evident from these reports. In a recent critical review of clinical trials that evaluated patients with acromegaly treated with first-generation somatostatin analogues from 1990 to March 2015, biochemical response rates ranged from 17 to $86 \%$ for octreotide LAR and 17 to $84 \%$ for lanreotide Autogel (Colao et al. 2016). Accounting for such disparity is complicated by multiple confounding variables that preclude direct comparisons between different studies. Although target threshold levels of biochemical control in the included studies are generally similar (ie, GH $\leq 2.5 \mu \mathrm{g} / \mathrm{L}$ and/or normalization of IGF-1), lack of standardization of GH and IGF-1 assays, different patient populations, inclusion or exclusion of treatment non-responders, use of composite endpoints (both mean GH and IGF-1 levels) and pre-treatment with medical therapy represent some of the key factors that can introduce bias into response rate reporting (Colao et al. 2016). Interestingly, in prospective studies using stringent composite measures of biochemical control to evaluate medical-treatment-naïve patients not pre-selected for responsiveness to prior somatostatin therapy, response rates are consistent, ranging from 17 to 37\% (Colao et al. 2016).

In the largest prospective, randomized, activecontrolled trial in medically naïve patients with acromegaly to date, pasireotide LAR was more effective at providing biochemical control (GH $<2.5 \mu \mathrm{g} / \mathrm{L}$ and normal IGF-1) than octreotide LAR (31.3\% vs $19.2 \%$, respectively) after 1 year of treatment (Colao et al. 2014). Pasireotide LAR had a similar safety profile as that of octreotide LAR, except for a higher frequency and degree of hyperglycaemia.

\section{Clinical utility as first-line therapy}

Removing or reducing the size of the tumour is another guidelines-recommended goal of treatment, with neurosurgery being the accepted first-line treatment. However, pre-operative medical treatment may achieve better post-operative outcomes, as tumour shrinkage (Sheppard 2003, Melmed et al. 2005), and softening of the tumour parenchyma (Stevenaert \& Beckers 1996, Abe \& Ludecke 2001) induced by somatostatin analogues likely

Published by Bioscientifica Ltd 
facilitates surgical resection. Octreotide LAR was shown in a recent meta-analysis to reduce tumour volume by $66.0 \%$ (95\% confidence interval (CI), 57.0-74.0) (Giustina et al. 2012). Tumour volume reduction is typically observable within 3 months of initiating therapy and lasts for up to 4 years in some patients (Lundin et al. 1997, Melmed et al. 2005), although tumour regrowth may occur upon discontinuation of medical treatment (van der Lely et al. $2001 b)$. The effect of primary lanreotide Autogel (120 mg) treatment on tumour size in treatment-naïve patients with $\mathrm{GH}$-secreting macroadenomas was specifically assessed in the recent PRIMARYS study (Caron et al. 2014). In the intention-to-treat population, $62.9 \%$ (95\% CI: 52.0-72.9) of 89 patients achieved clinically significant $(\geq 20 \%)$ tumour volume reduction at 48 weeks or last follow-up. However, because the lower confidence limit was below a predetermined threshold of $55 \%$, the study did not achieve its primary endpoint.

In a multicentre study, surgical remission (IGF- $1 \leq$ ageadjusted upper limit of normal (ULN)) at 3 months after surgery was achieved in half of newly diagnosed patients with macroadenomas who had received 6 months of pre-surgical treatment with octreotide LAR vs $16 \%$ who underwent surgery without pre-treatment (Carlsen et al. 2008). Long-term observational data ( 1 and 5 years post-operatively) for these patients, however, revealed no significant impact of pre-operative treatment on macroadenomas (Fougner et al. 2014). Remission rates (IGF-1 $\leq$ age-adjusted ULN) of 49 and $18 \%$ were found in a single-centre study of 98 patients with newly diagnosed macroadenomas who received 4-month pre-treatment with lanreotide Autogel before surgery or surgery without pre-treatment, respectively (Mao et al. 2010). Shen and coworkers reported that pre-surgical treatment of invasive macroadenomas with octreotide LAR increased total resection rates and short-term remission rates (both GH and IGF-1 normalized) vs no pre-treatment; however, remission rates during long-term follow-up of the pre-treated group showed no advantage (Shen et al. 2010). A retrospective analysis of 286 patients revealed that surgical remission rates were not significantly different whether octreotide or lanreotide was given pre-operatively or not (Losa et al. 2006). A recent meta-analysis suggested a statistically significant effect of pre-operative medical therapy on surgical outcome when three prospective controlled trials were analysed, with a pooled odds ratio for biochemical cure with somatostatin analogue pre-treatment of 3.62 (95\% CI: 1.88-6.96) (Pita-Gutierrez et al. 2013). It should be noted, however, that the beneficial effect of pre-treatment was demonstrated only in centres with low rates of cure with primary surgical treatment. Given the existing evidence, current guidelines do not advocate the routine use of pre-operative medical therapy (Katznelson et al. 2014).

\section{Improvements in symptoms, co-morbidities and reductions in excess mortality risk}

In addition to preventing continued tumour growth, medical therapy of pituitary tumours also provides marked relief of symptoms in up to $70 \%$ of patients with acromegaly. Reduced episodes of headache, fatigue, joint pain, carpal tunnel syndrome and perspiration with octreotide treatment have been noted (Vance \& Harris 1991, Ezzat et al. 1992, Newman et al. 1995). Disease-associated co-morbidities, including cardiac and respiratory disorders, also improve with somatostatin analogue therapy (Colao et al. 2008). This is particularly important given that cardiovascular co-morbidities serve as the major events that limit patient survival. Crucially, early diagnosis and normalization of GH or IGF-1 levels have been shown to ameliorate the excess mortality risk associated with acromegaly (Swearingen et al. 1998, Holdaway et al. 2008). Given that up to $40 \%$ of patients with acromegaly may show discordant GH and IGF-1 levels (Alexopoulou et al. 2008), achieving target levels of both biochemical measures is a better indicator of attaining a life expectancy equivalent to that of the general population (Holdaway et al. 2008).

\section{Therapeutic options for biochemically uncontrolled patients}

Despite the clinical success of somatostatin analogue therapy in the treatment of acromegaly, up to half of patients may be biochemically uncontrolled (Freda et al. 2005, Murray \& Melmed 2008, Colao et al. 2011, Carmichael et al. 2014). Although the reasons for not achieving biochemical control with somatostatin analogues are not fully elucidated, the phenomenon appears to be multifactorial, involving both clinical characteristics and molecular-based mechanisms (Gadelha et al. 2013). With respect to the latter, high tumour expression levels of SSTR2 generally predicts a successful response, whereas patients with low-SSTR2-expressing tumours exhibit resistance and have a correspondingly poorer response (Taboada et al. 2008, Gatto et al. 2013, Wildemberg et al. 2013). Interestingly, some patients with high-SSTR2-expressing tumours may also exhibit resistance (Kasuki et al. 2012).

Published by Bioscientifica Ltd. 
Clinical practice guidelines recommend assessing the efficacy of somatostatin analogue therapy after 3 months (Katznelson et al. 2014). In those patients who do not achieve adequate symptom or biochemical control with the starting dose of octreotide LAR, flexibility exists either to up-titrate or to decrease the dosing interval (Giustina et al. 2009, 2014, Fleseriu 2011, Mazziotti et al. 2011) (Fig. 2). Conversely, for patients who have achieved biochemical control with chronic octreotide LAR therapy, dosage can be reduced or the interval between doses can be extended beyond the recommended 4 weeks without compromising GH and IGF-1 levels or clinical response (Jenkins et al. 2000, Biermasz et al. 2003, Turner et al. 2004). For well-controlled patients receiving lanreotide Autogel 60 or $90 \mathrm{mg}$, the US Food and Drug Administration (FDA) has approved an extended dosing interval from 4 weeks to 6-8 weeks with an increase in the dose of lanreotide Autogel to $120 \mathrm{mg}$.

Withdrawal of chronic somatostatin analogue therapy is only a realistic option in those rare patients with persistent optimum control on relatively low doses administered at long intervals (Ramirez et al. 2012).

For patients partially controlled or uncontrolled on first-generation somatostatin analogue therapy, a number of therapeutic options are available, including monotherapy with either pasireotide LAR or the GH receptor antagonist pegvisomant. In the 24-week, Phase III PAOLA trial of 198 patients uncontrolled (mean GH $\geq 2.5 \mu \mathrm{g} / \mathrm{L}$ and IGF-1 $>1.3 \times$ ULN) on octreotide LAR or lanreotide Autogel treatment, patients were randomized to pasireotide LAR $40 \mathrm{mg}(n=65)$, pasireotide LAR $60 \mathrm{mg}$ $(n=65)$ or continued treatment with octreotide LAR $30 \mathrm{mg}$ or lanreotide Autogel $120 \mathrm{mg}$ (active control group; $n=68)$. Pasireotide LAR 40 and $60 \mathrm{mg}$ provided biochemical control in $15 \% \quad(P=0.0006$ vs active control) and $20 \%(P<0.0001$ vs active control $)$ of patients, respectively, compared with no patients in the control group (Gadelha et al. 2014). Pasireotide LAR had a similar safety profile as that of first-generation somatostatin analogues, except for a higher frequency and degree of hyperglycaemia.

In early registration trials of pegvisomant in patients with acromegaly, treatment resulted in normalization of IGF-1 in $82-97 \%$ of patients (Trainer et al. 2000, van der Lely et al. 2001a). Subsequent studies have reported lower rates of IGF-1 normalization of 51-78\% (Barkan et al. 2005, Schreiber et al. 2007, Ghigo et al. 2009, Trainer et al. 2009). In the global observational ACROSTUDY of 1288 patients with acromegaly receiving pegvisomant, $63.2 \%$ of patients had normal IGF-1 levels after 5 years of pegvisomant treatment (van der Lely et al. 2012). Pegvisomant has been generally well tolerated to date (Trainer et al. 2000, 2009, van der Lely et al. 2001a, Barkan et al. 2005, Schreiber et al. 2007, Ghigo et al. 2009), although regular monitoring of hepatic function and serial magnetic resonance imaging to evaluate tumour size are recommended (Katznelson et al. 2014).

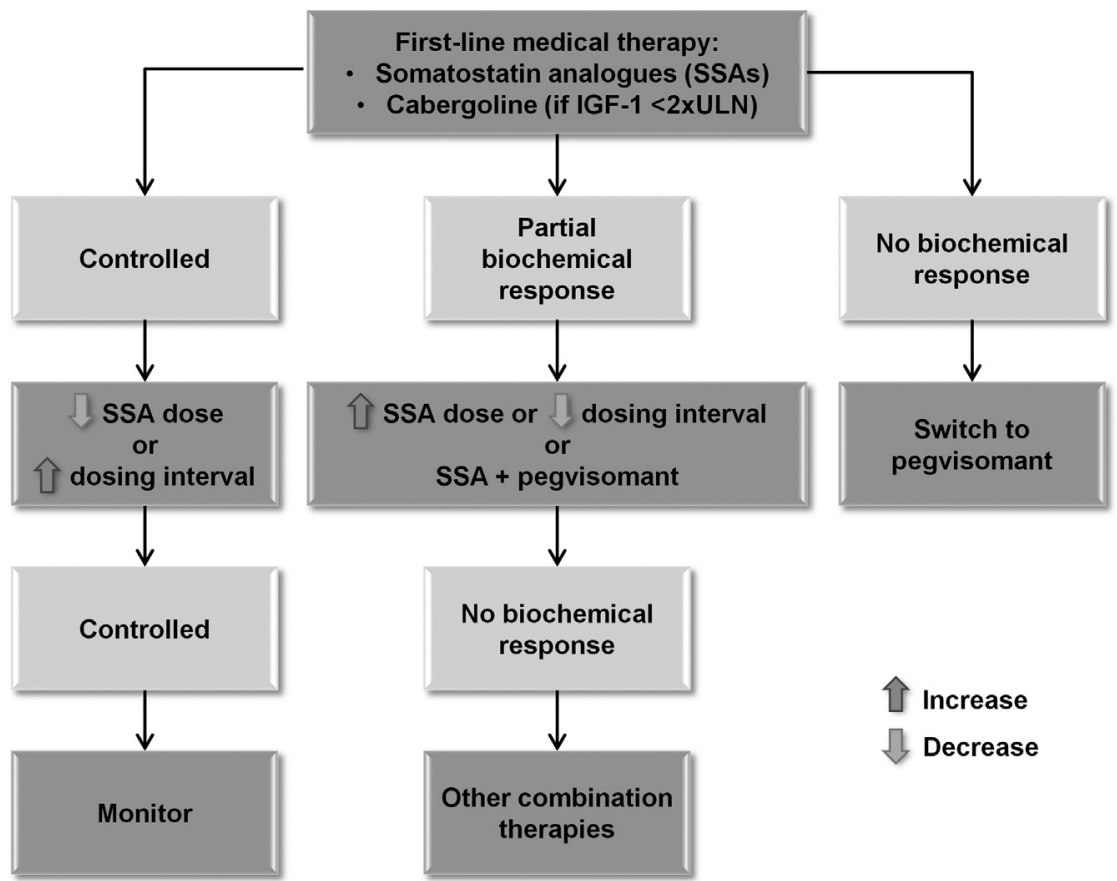

\section{Figure 2}

Algorithm for the approach to medical therapy in patients with acromegaly. Reproduced, with permission, from Giustina $A$, Chanson $P$, Kleinberg D, Bronstein MD, Clemmons DR, Klibanski A, van der Lely AJ, Strasburger CJ, Lamberts SW, Ho KKY, et al. (2014) Expert consensus document: a consensus on the medical treatment of acromegaly, Nature Reviews Endocrinology, volume 10, issue 4, pages 243-248. Copyright 2014, Rights Managed by Nature Publishing Group. 
Combination therapy may also be considered in patients exhibiting partial responses to first-generation somatostatin analogues despite dose adjustments (Fig. 2). Sandret and coworkers systematically reviewed all trials of the dopamine receptor agonist cabergoline for the treatment of acromegaly and found that cabergoline in combination with a somatostatin analogue normalized IGF-1 levels in approximately half of patients previously uncontrolled on somatostatin analogue therapy (Sandret et al. 2011). However, the effect of cabergoline was found to be dependent on the baseline IGF-1 level, with the best response being observed in patients with IGF-1 levels $<2 \times$ ULN.

In a single-centre study of 141 patients with acromegaly and persistently elevated IGF-1 levels $(>1.2 \times \mathrm{ULN})$ despite at least 6 months of somatostatin analogue therapy, treatment with pegvisomant in combination with somatostatin analogues (median treatment duration, 4.9 years) improved control of IGF-1 in $97.0 \%$ of patients (Neggers et al. 2014). Combination therapy was well tolerated, similarly as what has been observed with pegvisomant monotherapy.

In patients uncontrolled on primary somatostatin analogue therapy, tumour debulking has been shown to improve subsequent responses to first-generation somatostatin analogues (Petrossians et al. 2005) and thus may be a therapeutic option for some patients.

\section{Disease management considerations}

Cost effectiveness is an increasingly important consideration in management decisions in acromegaly (Ben-Shlomo et al. 2011). Although treatment costs are substantial, they are not significantly higher than those associated with other chronic diseases (Katznelson et al. 2011). However, as the cost effectiveness of medical therapies for acromegaly has not been comprehensively evaluated, more careful studies are required to better determine the cost/benefit ratio. The impact of chronic therapy on QoL is also a key consideration. Acromegaly is associated with substantially reduced QoL (Rowles et al. 2005, Kauppinen-Makelin et al. 2006, Webb 2006), in a similar manner as osteoarthritis (Rowles et al. 2005), whereas obese patients report better QoL scores in terms of appearance and general health (Rowles et al. 2005, Webb 2006). Improvements in biochemical control provided by octreotide LAR and lanreotide Autogel have been found to parallel improvements in QoL (Matta et al. 2008, Mangupli et al. 2014, Caron et al. 2016).

\section{Clinical experience: GEP-NET}

Radical surgery is the only 'curative' treatment for GEP-NET; however, with more than half of tumours being unresectable at diagnosis (Kim et al. 2010), symptoms caused by tumour-related hormone hypersecretion are managed with somatostatin analogue therapy. Short-acting octreotide was the first biotherapeutic agent used for the successful control of symptoms associated with carcinoid tumours, but it requires long-term administration of multiple daily injections. A randomized, double-blind study by Rubin and coworkers first demonstrated that octreotide LAR had similar efficacy to the short-acting formulation in the treatment of carcinoid syndrome once steady-state octreotide concentrations were achieved (Rubin et al. 1999). Octreotide LAR has since removed the need for daily injections, although breakthrough symptoms may still require treatment with its short-acting formulation. Pooled data from studies of octreotide in GEP-NET conducted between 1986 and 2004 indicate that up to $70 \%$ of patients experience resolution of diarrhoea or flushing with octreotide treatment (Modlin et al. 2006). Lanreotide has also shown comparable efficacy with octreotide in improving flushes and diarrhoea in patients with carcinoid syndrome, providing relief of symptoms in up to $80 \%$ of patients (Modlin et al. 2006).

\section{Antitumour effect}

Although somatostatin analogues have long been indicated for symptom relief associated with GEP-NET, there is a growing body of evidence to indicate associated antitumour activity. Although treatment for GEP-NET is multimodal, it has been speculated that the introduction of octreotide in 1987 and its subsequent clinical use has contributed to improved patient survival (Halfdanarson et al. 2008, Yao et al. 2008). Two analyses of the Surveillance, Epidemiology and End Results (SEER) database revealed a marked improvement in survival duration of patients with GEP-NET between 1988 and 2004 compared with patients diagnosed earlier (Yao et al. 2008), as well as an increase in survival of patients with pancreatic NET over the period 1973-2000 (Halfdanarson et al. 2008). In support of these findings, a review of 90 patients with carcinoid syndrome treated during the somatostatin analogue era had 5-year survival rates of $67 \%$ compared with $18 \%$ for historical controls (Anthony et al. 1996).

The antitumour effect of octreotide in clinical studies of patients with GEP-NET has been evaluated

Published by Bioscientifica Ltd 
in two reviews. Eriksson and Oberg found that, in studies of octreotide spanning its introduction up to the late 1990s, approximately half of the patients with GEP-NET achieved stabilization of tumour growth (i.e., no increase or decrease in tumour size), with 10-20\% showing tumour regression (Eriksson \& Oberg 1999). A more recent review that analysed trials conducted between 1987 and 2011 revealed that stable disease in patients with poorly differentiated, functioning or non-functioning GEP-NET was achieved in up to $86 \%$ treated with octreotide sc and up to $88 \%$ in those receiving octreotide LAR (Sideris et al. 2012). Partial tumour response (i.e., a predefined reduction in overall tumour load) reached 31 and 11\% for octreotide sc and octreotide LAR, respectively, broadly in agreement with the earlier findings by Eriksson and Oberg (Eriksson \& Oberg 1999). Partial response and stable disease rates for lanreotide are similar to those reported for octreotide (up to 31 and 78\%, respectively). Lanreotide Autogel has been less well studied than octreotide LAR in the treatment of GEP-NET. In one study in patients with well-differentiated GEP-NET, stable disease and partial tumour response were reported in 89 and $4 \%$ of patients, respectively (Martin-Richard et al. 2011).

PROMID was the first large trial to confirm the antitumour effect of octreotide LAR in a randomized setting (Rinke et al. 2009). In 85 treatment-naïve patients with well-differentiated metastatic GEP-NET of the midgut, median time to tumour progression was significantly extended with octreotide LAR (14.3 months (95\% CI: 11.0-28.8)) compared with placebo (6 months (95\% CI: 3.7-9.4)); stable disease was observed in 67 and $37 \%$ of patients treated with octreotide LAR and placebo, respectively. The antitumour response was more pronounced in patients with a hepatic tumour burden of $\leq 10 \%$. Notably, no differences in response were reported between functioning and non-functioning GEP-NET. Median survival time for both treatment groups could not be reliably determined. It is currently unclear as to whether octreotide therapy confers improved overall survival in patients with GEP-NET of the midgut. Despite some reservations concerning aspects of the study design (Yao et al. 2013), data from PROMID were significant enough to prompt updates to several treatment guidelines to recommend $20-30 \mathrm{mg}$ of octreotide LAR in patients with recurrent or unresectable GEP-NET (Anthony et al. 2010, Boudreaux et al. 2010, Kulke et al. 2011, Oberg et al. 2012). A treatment algorithm is shown in Fig. 3.
The Lanreotide Antiproliferative Response in Patients with GEP-NET (CLARINET) trial represents only the second Phase III randomized study to confirm the antitumour effect of somatostatin analogues. In this 96-week study, 204 medically naïve patients with well-differentiated or moderately differentiated non-functioning GEP-NET were randomized to receive either lanreotide Autogel $120 \mathrm{mg}$ or placebo. The primary endpoint of PFS was met, with lanreotide Autogel demonstrating superiority to placebo in prolonging PFS compared with placebo: median PFS was not reached with lanreotide Autogel vs 18 months with placebo (hazard ratio 0.47 ; 95\% CI: 0.30-0.73; $P<0.001)$. After 2 years of treatment, estimated rates of PFS were 65.1 and $33.0 \%$ in the lanreotide Autogel and placebo groups, respectively (Caplin et al. 2014).

Several key differences between the PROMID and CLARINET studies likely account for the longer PFS observed in the latter study. First, the patient population in the CLARINET study was more heterogeneous than that in the PROMID study, with $96 \%$ of patients exhibiting no disease progression 3-6 months before study randomization (Caplin et al. 2014). It is possible that tumours in patients who participated in the CLARINET trial were potentially less aggressive than those in PROMID. Secondly, the studies used different criteria for progression: the WHO criterion used in PROMID was a $25 \%$ increase in the product of tumour bi-dimensional diameters, which corresponds to a $44 \%$ increase according to the Response Evaluation Criteria in Solid Tumors (RECIST) used in CLARINET (Strosberg et al. 2015). Thus, PFS in PROMID would likely have been longer if it was assessed using RECIST criteria.

The molecular basis of the antiproliferative effect of octreotide in GEP-NET is largely unknown. Research conducted in cultured cells derived from tumours other than GEP-NET suggests that the octreotide-SSTR2 interaction is coupled to proliferative signalling pathways that directly or indirectly modulate cell cycling (Pagès et al. 1999), apoptosis (Ferrante et al. 2006) and angiogenesis (García de la Torre et al. 2002). Angiogenesis (in particular, the phosphoinositide 3-kinase/Akt/ mammalian target of rapamycin (mTOR) pathway) has been clinically validated as a therapeutic target following the finding that everolimus, an mTOR inhibitor, improved progression-free survival (PFS) compared with placebo in patients with well-differentiated pancreatic NET (Yao et al. 2011). A synergistic drug combination approach that exploits more than one mechanism of action has been shown to enhance antitumour activity in patients with GEP-NET. The randomized,

Published by Bioscientifica Ltd. 


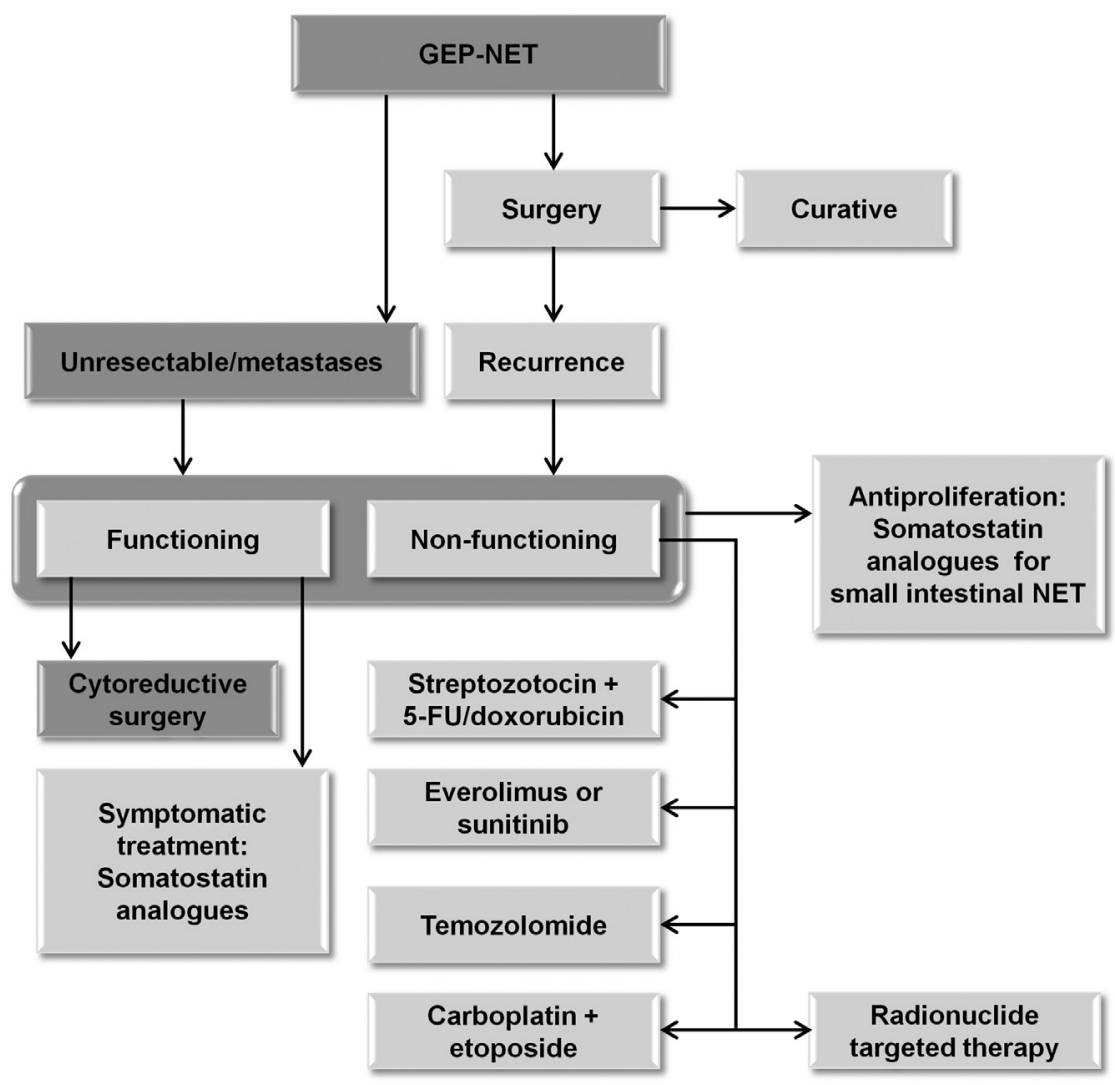

Figure 3

Algorithm for the treatment of GEP-NET. Adapted, with permission, from Oberg K, Knigge U, Kwekkeboom D \& Perren A, Neuroendocrine gastro-entero-pancreatic tumors: ESMO Clinical Practice Guidelines for diagnosis, treatment and follow-up, Annals of Oncology, 2012, volume 23 (Supplement 7), pages vii124-vii130, by permission of Oxford University Press. double-blind, placebo-controlled, Phase III RAD001 in Advanced Neuroendocrine Tumors (RADIANT-2) study evaluated everolimus in combination with octreotide LAR in patients with low- or intermediate-grade advanced NET (Pavel et al. 2011). Patients treated with everolimus plus octreotide LAR were more likely to experience tumour volume reduction than patients receiving placebo plus octreotide LAR (75\% vs 45\%, respectively). This combination led to a clinically meaningful 5.1-month improvement in PFS vs placebo plus octreotide LAR (16.4 vs 11.3 months). Concerns were expressed, however, that the patient population enrolled in RADIANT-2 was not as defined as that for PROMID, with diversity of tumours causing baseline imbalances that potentially affected outcomes (Yao et al. 2013).

\section{Safety and tolerability}

With two and a half decades of clinical experience, octreotide has a well-established safety profile. Adverse events associated with lanreotide are generally similar to those seen with octreotide. Gastrointestinal-related complaints are the most frequently reported side effects, being mild to moderate in severity and attributable to drug-induced disruption of GEP hormone signalling and reduced secretion of digestive enzymes (Bornschein et al. 2009). Altered secretion of cholecystokinin can lead to abnormalities in the biliary system (Moschetta et al. 2001). Up to one-third of patients with acromegaly may develop biliary sediment/sludge, microlithiasis or gallstones (Catnach et al. 1993, Lamberts et al. 1996, Attanasio et al. 2003, Plöckinger et al. 2008), whereas almost half of patients with advanced GEP-NET are at risk of developing gallstones and/or biliary sludge while receiving chronic first-generation somatostatin analogue therapy (Trendle et al. 1997).

In patients with acromegaly treated with octreotide, prolongation of the QT interval on electrocardiogram (ECG) has been observed with clinical symptoms of bradycardia (Novartis Pharmaceuticals 2012). Lanreotide-induced bradycardia is currently limited to one case report (Ogmen et al. 2015). It should be noted that untreated patients with acromegaly display ECG abnormalities: in a retrospective study of 30 patients with acromegaly, mean baseline QT interval corrected for heart rate (QTc) was significantly longer in patients than in healthy volunteer controls $(438.6 \pm 4.83 \mathrm{~ms}$ vs $407.9 \pm 5.86 \mathrm{~ms}, P<0.001$ ) (Fatti et al. 2006). Moreover, in a subset of patients $(n=24)$ treated with long-term somatostatin analogue therapy, QTc decreased significantly in

Published by Bioscientifica Ltd. 
patients to mean levels comparable with controls (from $436.5 \pm 4.89 \mathrm{~ms}$ to $421.0 \pm 6.06 \mathrm{~ms}, P<0.001$ ).

First-generation somatostatin analogues have the potential to alter glucose homeostasis, although individual responses in terms of glucose tolerance vary widely (Ronchi et al. 2002, Baldelli et al. 2003). In a prospective, non-randomized, 5-year study of 100 patients treated with surgery, somatostatin analogues or both (in a crossover design), a decrease in fasting glucose levels occurred only in those patients treated with medical therapy alone (Colao et al. 2009). However, a meta-analysis by Mazziotti and coworkers could not confirm an influence of somatostatin analogues on fasting glucose levels (Mazziotti et al. 2009). Patients with diabetes mellitus are, nevertheless, recommended to control their blood sugar levels strictly.

Pasireotide has a similar safety profile as that of firstgeneration somatostatin analogues, except for a higher frequency and degree of hyperglycaemia (Colao et al. 2012, 2014, Gadelha et al. 2014). Increases in blood glucose levels associated with pasireotide treatment are attributable to its receptor-binding profile (Bruns et al. 2002, Schmid \& Brueggen 2012). At present, it is unclear how the deterioration in glucose metabolism fits with the improved GH/IGF-1 levels.

\section{The shape of things to come}

\section{Oral octreotide}

In a recent Phase III trial, 98/151 (65\%) patients with acromegaly, previously controlled with somatostatin analogue therapy, maintained biochemical control $(\mathrm{GH}$ $<2.5 \mathrm{ng} / \mathrm{mL}$ and IGF- $1<1.3 \times \mathrm{ULN})$ after being switched to an oral formulation of octreotide (Octreolin) for up to 7 months (Melmed et al. 2015). Fifteen percent and 11\% of patients discontinued because of treatment failure (IGF-1>1.3 $\times$ ULN) and possible drug-related adverse events, respectively. There were two deaths reported: one from myocardial infarction and another from suspected biliary obstruction and sepsis. Although these findings are preliminary, the efficacy and safety profile of Octreolin are consistent with those of current injectable somatostatin analogue therapies and may potentially offer improved convenience.

\section{Octreotide sc depot}

Despite the established clinical credentials of octreotide LAR, this formulation requires a multistep reconstitution process and a requirement for intramuscular injection, both of which must be performed by health care professionals. Octreotide sc depot is a novel formulation of octreotide based on liquid-lipid-crystal technology (Tiberg \& Johnsson 2011, Tiberg et al. 2012a,b) that permits the use of thin needles for sc injection with planned availability in prefilled syringes. In a Phase I pharmacokinetic (PK) and pharmacodynamic (PD) study, octreotide sc depot provided greater octreotide bioavailability, with more rapid onset and similar duration of PD effect (in terms of IGF-1 suppression), compared with octreotide LAR in healthy volunteers (Tiberg et al. 2015). The improved PK/PD profile and the practical advantages of the sc depot formulation over the currently marketed LAR formulation (including the potential for self-administration or partner administration) mark this novel drug-delivery technology as a significant advancement over the existing polymer-based system. Phase II and III studies will further evaluate octreotide sc depot in patients with acromegaly and GEP-NET.

\section{Pasireotide LAR in GEP-NET}

Pasireotide has demonstrated effective symptom control in patients with GEP-NET: in a Phase II, multicentre study of 44 patients with advanced GEP-NET whose symptoms were refractory or resistant to octreotide LAR, pasireotide treatment provided relief of symptoms (diarrhoea and flushing) in 27\% of patients (Kvols et al. 2012). Additionally, in a Phase III study of pasireotide LAR vs high-dose $(40 \mathrm{mg}$ ) octreotide LAR in 110 patients with advanced GEP-NET whose disease-related symptoms were uncontrolled by first-generation somatostatin analogues at maximum approved doses, pasireotide LAR and octreotide LAR had similar effects on symptom control (Wolin et al. 2015). These data warrant further investigation into the role of pasireotide LAR in the treatment of GEP-NET.

\section{Peptide receptor radionuclide therapy in NET}

The incorporation of somatostatin analogues into radiopharmaceuticals allows for targeted delivery of radiation to SSTR-expressing tumours. The efficacy of [177 Lu]-DOTATATE (Lutathera), a conjugate consisting of octreotate radiolabelled with ${ }^{177} \mathrm{Lu}$, has been evaluated in patients with advanced midgut NET in the NETTER-1 Phase III study (Strosberg et al. 2016); 230 patients were randomized $(1: 1)$ to receive $\left[{ }^{177} \mathrm{Lu}\right]$-DOTATATE and octreotide LAR $60 \mathrm{mg}$. Preliminary analysis

Published by Bioscientifica Ltd. 
showed that, compared with high-dose octreotide LAR, fewer patients experienced disease progression with $\left[{ }^{177} \mathrm{Lu}\right]$-DOTATATE (23 vs 64 patients, respectively), median PFS was extended (8 months vs not reached) and there were substantially fewer deaths (13 vs 22 ) (Strosberg et al. 2016). Longer follow-up will better determine the impact of $\left.{ }^{177} \mathrm{Lu}\right]$-DOTATATE on overall survival. Peptide receptor radionuclide therapy may also use somatostatin-based conjugates radiolabelled with ${ }^{90} \mathrm{Y}$ for internal radiotherapy after systemic application. Although ${ }^{90} \mathrm{Y}$ has greater tissue penetration and a longer half-life than ${ }^{177} \mathrm{Lu}$ (Kam et al. 2012), one study in patients with advanced NET showed no difference in median overall survival between the two radionuclides; however, renal toxicity was more evident with ${ }^{90} \mathrm{Y}$ (Romer et al. 2014). Combination therapy with ${ }^{90} \mathrm{Y}$ and ${ }^{177} \mathrm{Lu}$ may be a more effective therapeutic approach than either radioisotope alone (Villard et al. 2012).

\section{Conclusions}

First-generation somatostatin analogues are efficacious in the treatment of acromegaly and symptom control in GEP-NET, with a favourable safety profile based on more than 25 years of clinical experience with octreotide. A growing body of clinical evidence supports the antitumour activity of somatostatin analogues, reducing tumour bulk in acromegaly and slowing tumour growth in GEP-NET. Whether this antitumour effect translates into a survival benefit will require further controlled trials in a larger number of patients with GEP-NET. Despite the impressive credentials, some patients with acromegaly remain uncontrolled with either octreotide or lanreotide therapy. Pasireotide is an effective alternative treatment option for some of these patients, although hyperglycaemia needs to be monitored and managed. First-generation somatostatin analogues continue to evolve with the development and introduction of new formulations that promise improved patient benefits.

\section{Declaration of interest}

Dr K Öberg has received honoraria and speaker fees from Novartis and IPSEN and served on advisory boards for Novartis, IPSEN and AAA Pharmaceuticals. Dr S W J Lamberts has in the past received honoraria and speaker fees from Novartis and IPSEN and served on advisory boards for Novartis and IPSEN.

\section{Funding}

Financial support for medical editorial assistance was provided by Novartis Pharmaceuticals Corporation.

\section{Acknowledgements}

The authors thank Richard Ogilvy-Stewart PhD, Mudskipper Business Ltd, for medical editorial assistance with this manuscript.

\section{References}

Abe T \& Ludecke DK 2001 Effects of preoperative octreotide treatment on different subtypes of $90 \mathrm{GH}$-secreting pituitary adenomas and outcome in one surgical centre. European Journal of Endocrinology $\mathbf{1 4 5}$ 137-145. (doi:10.1530/eje.0.1450137)

Ahmed S, Elsheikh M, Stratton IM, Page RC, Adams CB \& Wass JA 1999 Outcome of transphenoidal surgery for acromegaly and its relationship to surgical experience. Clinical Endocrinology 50 561-567. (doi:10.1046/j.1365-2265.1999.00760.x)

Alexopoulou O, Bex M, Abs R, T'Sjoen G, Velkeniers B \& Maiter D 2008 Divergence between growth hormone and insulin-like growth factor-i concentrations in the follow-up of acromegaly. Journal of Clinical Endocrinology and Metabolism 93 1324-1330. (doi:10.1210/ jc.2007-2104)

Anthony LB, Martin W, Delbeke D \& Sandler M 1996 Somatostatin receptor imaging: predictive and prognostic considerations. Digestion 57 (Supplement 1) 50-53. (doi:10.1159/000201396)

Anthony LB, Strosberg JR, Klimstra DS, Maples WJ, O’Dorisio TM, Warner RR, Wiseman GA, Benson AB III \& Pommier RF 2010 The NANETS consensus guidelines for the diagnosis and management of gastrointestinal neuroendocrine tumors (nets): well-differentiated nets of the distal colon and rectum. Pancreas 39 767-774. (doi:10.1097/MPA.0b013e3181ec1261)

Astruc B, Marbach P, Bouterfa H, Denot C, Safari M, Vitaliti A \& Sheppard M 2005 Long-acting octreotide and prolonged-release lanreotide formulations have different pharmacokinetic profiles. Journal of Clinical Pharmacology 45 836-844. (doi:10.1177/0091270005277936)

Attal P \& Chanson P 2010 Endocrine aspects of obstructive sleep apnea. Journal of Clinical Endocrinology and Metabolism 95 483-495. (doi:10.1210/jc.2009-1912)

Attanasio R, Baldelli R, Pivonello R, Grottoli S, Bocca L, Gasco V, Giusti M, Tamburrano G, Colao A \& Cozzi R 2003 Lanreotide 60 mg, a new long-acting formulation: effectiveness in the chronic treatment of acromegaly. Journal of Clinical Endocrinology and Metabolism 88 5258-5265. (doi:10.1210/jc.2003-030266)

Baldelli R, Battista C, Leonetti F, Ghiggi M-R, Ribaudo M-C, Paoloni A, D'Amico E, Ferretti E, Baratta R, Liuzzi A, et al. 2003 Glucose homeostasis in acromegaly: effects of long-acting somatostatin analogues treatment. Clinical Endocrinology 59 492-499. (doi:10.1046/j.1365-2265.2003.01876.x)

Barkan AL, Burman P, Clemmons DR, Drake WM, Gagel RF, Harris PE, Trainer PJ, van der Lely AJ \& Vance ML 2005 Glucose homeostasis and safety in patients with acromegaly converted from long-acting octreotide to pegvisomant. Journal of Clinical Endocrinology and Metabolism 90 5684-5691. (doi:10.1210/jc.2005-0331)

Bauer W, Briner U, Doepfner W, Haller R, Huguenin R, Marbach P, Petcher TJ \& Pless J 1982 SMS 201-995: a very potent and selective octapeptide analogue of somatostatin with prolonged action. Life Science 31 1133-1140. (doi:10.1016/0024-3205(82)90087-X)

Ben-Shlomo A, Sheppard MC, Stephens JM, Pulgar S \& Melmed S 2011 Clinical, quality of life, and economic value of acromegaly disease control. Pituitary 14 284-294. (doi:10.1007/s11102-011-0310-7)

Biering H, Knappe G, Gerl H \& Lochs H 2000 [Prevalence of diabetes in acromegaly and Cushing's disease]. Acta Medica Austriaca 27 27-31. (doi:10.1046/j.1563-2571.2000.00106.x)

Biermasz NR, van den Oever NC, Frolich M, Arias AM, Smit JW, Romijn JA \& Roelfsema F 2003 Sandostatin LAR in acromegaly: a 6-week injection interval suppresses GH secretion as effectively as a 
4-week interval. Clinical Endocrinology 58 288-295. (doi:10.1046/j.1365-2265.2003.01710.x)

Biermasz NR, Van Thiel SW, Pereira AM, Hoftijzer HC, van Hemert AM, Smit JW, Romijn JA \& Roelfsema F 2004 Decreased quality of life in patients with acromegaly despite long-term cure of growth hormone excess. Journal of Clinical Endocrinology and Metabolism 89 5369-5376. (doi:10.1210/jc.2004-0669)

Bornschein J, Drozdov I \& Malfertheiner P 2009 Octreotide LAR: safety and tolerability issues. Expert Opinion on Drug Safety 8 755-768. (doi:10.1517/14740330903379525)

Boudreaux JP, Klimstra DS, Hassan MM, Woltering EA, Jensen RT, Goldsmith SJ, Nutting C, Bushnell DL, Caplin ME \& Yao JC 2010 The NANETS consensus guideline for the diagnosis and management of neuroendocrine tumors: well-differentiated neuroendocrine tumors of the Jejunum, Ileum, Appendix, and Cecum. Pancreas 39 753-766. (doi:10.1097/MPA.0b013e3181ebb2a5)

Brazeau P, Vale W, Burgus R, Ling N, Butcher M, Rivier J \& Guillemin R 1973 Hypothalamic polypeptide that inhibits the secretion of immunoreactive pituitary growth hormone. Science 179 77-79. (doi:10.1126/science.179.4068.77)

Bruns C, Lewis I, Briner U, Meno-Tetang G \& Weckbecker G 2002 SOM230: a novel somatostatin peptidomimetic with broad somatotropin release inhibiting factor (SRIF) receptor binding and a unique antisecretory profile. European Journal of Endocrinology 146 707-716. (doi:10.1530/eje.0.1460707)

Caplin ME, Pavel M, Cwikla JB, Phan AT, Raderer M, Sedlácková E, Cadiot G, Wolin EM, Capdevila J, Wall L, et al. 2014 Lanreotide in metastatic enteropancreatic neuroendocrine tumors. New England Journal of Medicine 371 224-233. (doi:10.1056/NEJMoa1316158)

Carlsen SM, Lund-Johansen M, Schreiner T, Aanderud S, Johannesen O, Svartberg J, Cooper JG, Hald JK, Fougner SL \& Bollerslev J 2008 Preoperative octreotide treatment in newly diagnosed acromegalic patients with macroadenomas increases cure short-term postoperative rates: a prospective, randomized trial. Journal of Clinical Endocrinology and Metabolism 93 2984-2990. (doi:10.1210/ jc.2008-0315)

Carmichael JD, Bonert VS, Nuño M, Ly D \& Melmed S 2014 Acromegaly clinical trial methodology impact on reported biochemical efficacy rates of somatostatin receptor ligand treatments - a meta-analysis. Journal of Clinical Endocrinology and Metabolism 99 1825-1833. (doi:10.1210/jc.2013-3757)

Caron P, Beckers A, Cullen DR, Goth MI, Gutt B, Laurberg P, Pico AM, Valimaki M \& Zgliczynski W 2002 Efficacy of the new long-acting formulation of lanreotide (lanreotide Autogel) in the management of acromegaly. Journal of Clinical Endocrinology and Metabolism $\mathbf{8 7}$ 99-104. (doi:10.1210/jcem.87.1.8153)

Caron PJ, Bevan JS, Petersenn S, Flanagan D, Tabarin A, Prévost G, Maisonobe P \& Clermont A 2014 Tumor shrinkage with lanreotide Autogel $120 \mathrm{mg}$ as primary therapy in acromegaly: results of a prospective multicenter clinical trial. Journal of Clinical Endocrinology and Metabolism 99 1282-1290. (doi:10.1210/jc.2013-3318)

Caron PJ, Bevan JS, Petersenn S, Houchard A, Sert C \& Webb SM 2016 Effects of lanreotide Autogel primary therapy on symptoms and quality-of-life in acromegaly: data from the PRIMARYS study. Pituitary 19 149-157. (doi:10.1007/s11102-015-0693-y)

Catnach SM, Anderson JV, Fairclough PD, Trembath RC, Wilson PA, Parker E, Besser GM \& Wass JA 1993 Effect of octreotide on gall stone prevalence and gall bladder motility in acromegaly. Gut $\mathbf{3 4}$ 270-273. (doi:10.1136/gut.34.2.270)

Colao A, Auriemma RS, Pivonello R, Galdiero M \& Lombardi G 2008 Medical consequences of acromegaly: what are the effects of biochemical control? Reviews in Endocrine and Metabolic Disorders 9 21-31. (doi:10.1007/s11154-007-9062-0)

Colao A, Auriemma RS, Galdiero M, Cappabianca P, Cavallo LM, Esposito F, Grasso LF, Lombardi G \& Pivonello R 2009 Impact of somatostatin analogs vs. surgery on glucose metabolism in acromegaly: results of a 5-year observational, open, prospective study. Journal of Clinical Endocrinology and Metabolism 94 528-537. (doi:10.1210/jc.2008-1546)

Colao A, Auriemma RS, Lombardi G \& Pivonello R 2011 Resistance to somatostatin analogs in acromegaly. Endocrine Reviews 32 247-271. (doi:10.1210/er.2010-0002)

Colao A, Petersenn S, Newell-Price J, Findling JW, Gu F, Maldonado M, Schoenherr U, Mills D, Salgado LR \& Biller BMK 2012 A 12-month phase 3 study of pasireotide in Cushing's disease. New England Journal of Medicine 366 914-924. (doi:10.1056/NEJMoa1105743)

Colao A, Bronstein MD, Freda P, Gu F, Shen C-C, Gadelha M, Fleseriu M, van der Lely AJ, Farrall AJ, Hermosillo Reséndiz K, et al. 2014 Pasireotide versus octreotide in acromegaly: a head-to-head superiority study. Journal of Clinical Endocrinology and Metabolism 99 791-799. (doi:10.1210/jc.2013-2480)

Colao A, Auriemma RS, Pivonello R, Kasuki L \& Gadelha MR 2016 Interpreting biochemical control response rates with first-generation somatostatin analogues in acromegaly. Pituitary 19 235-247. (doi:10.1007/s11102-015-0684-z)

Dal J, Feldt-Rasmussen U, Andersen M, Kristensen LO, Laurberg P, Pedersen L, Dekkers OM, Sorensen HT \& Jorgensen JO 2016 Acromegaly incidence, prevalence, complications, and long-term prognosis: a nationwide cohort study. European Journal of Endocrinology 175 181-190. (doi:10.1530/EJE-16-0117)

de Herder WW, Hofland LJ, van der Lely AJ \& Lamberts SW 2003 Somatostatin receptors in gastroentero-pancreatic neuroendocrine tumours. Endocrine-Related Cancer 10 451-458. (doi:10.1677/ erc.0.0100451)

Dekkers OM, Biermasz NR, Pereira AM, Romijn JA \& Vandenbroucke JP 2008 Mortality in acromegaly: a metaanalysis. Journal of Clinical Endocrinology and Metabolism 93 61-67. (doi:10.1210/jc.2007-1191)

Dietrich H, Hu K, Ruffin M, Song D, Bouillaud E, Wang Y \& Hasskarl J 2012 Safety, tolerability and pharmacokinetics of a single dose of pasireotide long-acting release (LAR) in healthy volunteers: a single-center Phase I study. European Journal of Endocrinology 166 821-828. (doi:10.1530/EJE-11-0773)

Drange MR, Fram NR, Herman-Bonert V \& Melmed S 2000 Pituitary tumor registry: a novel clinical resource. Journal of Clinical Endocrinology and Metabolism 85 168-174. (doi:10.1210/jc.85.1.168)

Eriksson B \& Oberg K 1999 Summing up 15 years of somatostatin analog therapy in neuroendocrine tumors: future outlook. Annals of Oncology 10 (Supplement 2) S31-S38. (doi:10.1093/annonc/10. suppl_2.S31)

Ezzat S, Snyder PJ, Young WF, Boyajy LD, Newman C, Klibanski A, Molitch ME, Boyd AE, Sheeler L, Cook DM, et al. 1992 Octreotide treatment of acromegaly. A randomized, multicenter study. Annals of Internal Medicine 117 711-718. (doi:10.7326/0003-4819. 117-9-711)

Fatti LM, Scacchi M, Lavezzi E, Giraldi FP, De Martin M, Toja P, Michailidis G, Stramba-Badiale M \& Cavagnini F 2006 Effects of treatment with somatostatin analogues on QT interval duration in acromegalic patients. Clinical Endocrinology 65 626-630. (doi:10.1111/j.1365-2265.2006.02639.x)

Ferrante E, Pellegrini C, Bondioni S, Peverelli E, Locatelli M, Gelmini P, Luciani P, Peri A, Mantovani G, Bosari S, et al. 2006 Octreotide promotes apoptosis in human somatotroph tumor cells by activating somatostatin receptor type 2. Endocrine-Related Cancer 13 955-962. (doi:10.1677/erc.1.01191)

Fleseriu M 2011 Clinical efficacy and safety results for dose escalation of somatostatin receptor ligands in patients with acromegaly: a literature review. Pituitary 14 184-193. (doi:10.1007/s11102-0100282-z)

Fougner SL, Bollerslev J, Svartberg J, Øksnes M, Cooper J \& Carlsen SM 2014 Preoperative octreotide treatment of acromegaly: long-term results of a randomised controlled trial. European Journal of Endocrinology 171 229-235. (doi:10.1530/EJE-14-0249) 
Freda PU, Katznelson L, van der Lely AJ, Reyes CM, Zhao S \& Rabinowitz D 2005 Long-acting somatostatin analog therapy of acromegaly: a meta-analysis. Journal of Clinical Endocrinology and Metabolism 90 4465-4473. (doi:10.1210/jc.2005-0260)

Gadelha MR, Kasuki L \& Korbonits M 2013 Novel pathway for somatostatin analogs in patients with acromegaly. Trends in Endocrinology and Metabolism 24 238-246. (doi:10.1016/j. tem.2012.11.007)

Gadelha MR, Bronstein MD, Brue T, Coculescu M, Fleseriu M, Guitelman M, Pronin V, Raverot G, Shimon I, Lievre KK, et al. 2014 Pasireotide versus continued treatment with octreotide or lanreotide in patients with inadequately controlled acromegaly (PAOLA): a randomised, phase 3 trial. Lancet Diabetes \& Endocrinology 2 875-884. (doi:10.1016/s2213-8587(14)70169-x)

García de la Torre N, Wass JA \& Turner HE 2002 Antiangiogenic effects of somatostatin analogues. Clinical Endocrinology 57 425-441. (doi:10.1046/j.1365-2265.2002.01619.x)

Gatto F, Feelders RA, van der Pas R, Kros JM, Waaijers M, Sprij-Mooij D, Neggers SJ, van der Lelij AJ, Minuto F, Lamberts SW, et al. 2013 Immunoreactivity score using an anti-sst $2 \mathrm{~A}$ receptor monoclonal antibody strongly predicts the biochemical response to adjuvant treatment with somatostatin analogs in acromegaly. Journal of Clinical Endocrinology and Metabolism 98 E66-E71. (doi:10.1210/ jc.2012-2609)

Ghigo E, Biller BM, Colao A, Kourides IA, Rajicic N, Hutson RK, De ML \& Klibanski A 2009 Comparison of pegvisomant and long-acting octreotide in patients with acromegaly naive to radiation and medical therapy. Journal of Endocrinological Investigation 32 924-933. (doi:10.1007/BF03345774)

Gittoes NJ, Sheppard MC, Johnson AP \& Stewart PM 1999 Outcome of surgery for acromegaly - the experience of a dedicated pituitary surgeon. QJM 92 741-745. (doi:10.1093/qjmed/92.12.741)

Giustina A, Bonadonna S, Bugari G, Colao A, Cozzi R, Cannavo S, De Marinis L, Degli Uberti E, Bogazzi F, Mazziotti G, et al. 2009 High-dose intramuscular octreotide in patients with acromegaly inadequately controlled on conventional somatostatin analogue therapy: a randomised controlled trial. European Journal of Endocrinology 161 331-338. (doi:10.1530/EJE-09-0372)

Giustina A, Mazziotti G, Torri V, Spinello M, Floriani I \& Melmed S 2012 Meta-analysis on the effects of octreotide on tumor mass in acromegaly. PLOS ONE 7 e36411. (doi:10.1371/journal.pone.0036411)

Giustina A, Chanson P, Kleinberg D, Bronstein MD, Clemmons DR, Klibanski A, van der Lely AJ, Strasburger CJ, Lamberts SW, Ho KK, et al. 2014 Expert consensus document: a consensus on the medical treatment of acromegaly. Nature Reviews Endocrinology 10 243-248. (doi:10.1038/nrendo.2014.21)

Halfdanarson TR, Rabe KG, Rubin J \& Petersen GM 2008 Pancreatic neuroendocrine tumors (PNETs): incidence, prognosis and recent trend toward improved survival. Annals of Oncology 19 1727-1733. (doi:10.1093/annonc/mdn351)

Hofland LJ \& Lamberts SW 2003 The pathophysiological consequences of somatostatin receptor internalization and resistance. Endocrine Reviews 24 28-47. (doi:10.1210/er.2000-0001)

Holdaway IM, Bolland MJ \& Gamble GD 2008 A meta-analysis of the effect of lowering serum levels of GH and IGF-I on mortality in acromegaly. European Journal of Endocrinology 159 89-95. (doi:10.1530/EJE-08-0267)

Jenkins PJ, Akker S, Chew SL, Besser GM, Monson JP \& Grossman AB 2000 Optimal dosage interval for depot somatostatin analogue therapy in acromegaly requires individual titration. Clinical Endocrinology 53 719-724. (doi:10.1046/j.1365-2265.2000.01168.x)

Kam BL, Teunissen JJ, Krenning EP, de Herder WW, Khan S, van Vliet EI \& Kwekkeboom DJ 2012 Lutetium-labelled peptides for therapy of neuroendocrine tumours. European Journal of Nuclear Medicine and Molecular Imaging 39 (Supplement 1) S103-S112. (doi:10.1007/ s00259-011-2039-y)
Kasayama S, Otsuki M, Takagi M, Saito H, Sumitani S, Kouhara H, Koga M, Saitoh Y, Ohnishi T \& Arita N 2000 Impaired beta-cell function in the presence of reduced insulin sensitivity determines glucose tolerance status in acromegalic patients. Clinical Endocrinology 52 549-555. (doi:10.1046/j.1365-2265.2000.00986.x)

Kasuki L, Colli LM, Elias PC, Castro M \& Gadelha MR 2012 Resistance to octreotide LAR in acromegalic patients with high SSTR2 expression: analysis of AIP expression. Arquivos Brasileiros de Endocrinologia \& Metabologia 56 501-506. (doi:10.1590/s000427302012000800007)

Katznelson L, Atkinson JL, Cook DM, Ezzat SZ, Hamrahian AH \& Miller KK 2011 American Association of Clinical Endocrinologists medical guidelines for clinical practice for the diagnosis and treatment of acromegaly - 2011 update. Endocrine Practice 17 (Supplement 4) 1-44. (doi:10.4158/EP.17.S4.1)

Katznelson L, Laws ER Jr, Melmed S, Molitch ME, Murad MH, Utz A \& Wass JA 2014 Acromegaly: an endocrine society clinical practice guideline. Journal of Clinical Endocrinology and Metabolism 99 3933-3951. (doi:10.1210/jc.2014-2700)

Kauppinen-Makelin R, Sane T, Sintonen H, Markkanen H, Valimaki MJ, Loyttyniemi E, Niskanen L, Reunanen A \& Stenman UH 2006 Quality of life in treated patients with acromegaly. Journal of Clinical Endocrinology and Metabolism 91 3891-3896. (doi:10.1210/jc.20060676)

Kim SJ, Kim JW, Han SW, Oh DY, Lee SH, Kim DW, Im SA, Kim TY, Seog HD \& Bang YJ 2010 Biological characteristics and treatment outcomes of metastatic or recurrent neuroendocrine tumors: tumor grade and metastatic site are important for treatment strategy. BMC Cancer 10 448. (doi:10.1186/1471-2407-10-448)

Kleinberg DL 2005 Primary therapy for acromegaly with somatostatin analogs and a discussion of novel peptide analogs. Reviews in Endocrine and Metabolic Disorders 6 29-37. (doi:10.1007/s11154-0055222-2)

Kulke MH, Siu LL, Tepper JE, Fisher G, Jaffe D, Haller DG, Ellis LM, Benedetti JK, Bergsland EK, Hobday TJ, et al. 2011 Future directions in the treatment of neuroendocrine tumors: consensus report of the National Cancer Institute Neuroendocrine Tumor clinical trials planning meeting. Journal of Clinical Oncology 29 934-943. (doi:10.1200/JCO.2010.33.2056)

Kvols L, Oberg KE, O’Dorisio T, Mohideen P, de Herder WW, Arnold R, Hu K, Zhang Y, Hughes G, Anthony L, et al. 2012 Pasireotide (SOM230) shows efficacy and tolerability in the treatment of patients with advanced neuroendocrine tumors refractory or resistant to octreotide LAR: results from a phase II study. Endocrine-Related Cancer 19 657-666. (doi:10.1530/ERC-11-0367)

Lamberts SW, Oosterom R, Neufeld M \& del Pozo E 1985a The somatostatin analog SMS 201-995 induces long-acting inhibition of growth hormone secretion without rebound hypersecretion in acromegalic patients. Journal of Clinical Endocrinology and Metabolism 60 1161-1165. (doi:10.1210/jcem-60-6-1161)

Lamberts SW, Uitterlinden P, Verschoor L, van Dongen KJ \& del Pozo E $1985 b$ Long-term treatment of acromegaly with the somatostatin analogue SMS 201-995. New England Journal of Medicine 313 1576-1580. (doi:10.1056/NEJM198512193132504)

Lamberts SW, van der Lely AJ, de Herder WW \& Hofland LJ 1996 Octreotide. New England Journal of Medicine 334 246-254. (doi:10.1056/NEJM199601253340408)

Lancranjan I, Bruns C, Grass P, Jaquet P, Jervell J, Kendall-Taylor P, Lamberts SWJ, Marbach P, Orskov H, Pagani G, et al. 1995 Sandostatin LAR: pharmacokinetics, pharmacodynamics, efficacy, and tolerability in acromegalic patients. Metabolism 44 (Supplement 1) 18-26. (doi:10.1016/0026-0495(95)90306-2)

Leon-Carrion J, Martin-Rodriguez JF, Madrazo-Atutxa A, Soto-Moreno A, Venegas-Moreno E, Torres-Vela E, Benito-López P, Galvez MA, Tinahones FJ \& Leal-Cerro A 2010 Evidence of cognitive and neurophysiological impairment in patients with untreated naive 
acromegaly. Journal of Clinical Endocrinology and Metabolism 95 4367-4379. (doi:10.1210/jc.2010-0394)

Lombardi G, Galdiero M, Auriemma RS, Pivonello R \& Colao A 2006 Acromegaly and the cardiovascular system. Neuroendocrinology $\mathbf{8 3}$ 211-217. (doi:10.1159/000095530)

Losa M, Mortini P, Urbaz L, Ribotto P, Castrignano T \& Giovanelli M 2006 Presurgical treatment with somatostatin analogs in patients with acromegaly: effects on the remission and complication rates. Journal of Neurosurgury 104 899-906. (doi:10.3171/ jns.2006.104.6.899)

Lundin P, Eden EB, Karlsson FA \& Burman P 1997 Long-term octreotide therapy in growth hormone-secreting pituitary adenomas: evaluation with serial MR. American Journal of Neuroradiology 18 765-772.

Mangupli R, Camperos P \& Webb SM 2014 Biochemical and quality of life responses to octreotide-LAR in acromegaly. Pituitary 17 495-499. (doi:10.1007/s11102-013-0533-x)

Mao ZG, Zhu YH, Tang HL, Wang DY, Zhou J, He DS, Lan H, Luo BN \& Wang HJ 2010 Preoperative lanreotide treatment in acromegalic patients with macroadenomas increases short-term postoperative cure rates: a prospective, randomised trial. European Journal of Endocrinology 162 661-666. (doi:10.1530/EJE-09-0908)

Martin-Richard M, Alonso V, Marmol M, Castellano DE, Fonseca E, Velasco A, Garcia JL, Rivera F, Galan A, Quindos M, et al. 2011 Evaluation of the efficacy and the safety of lanreotide autogel 120 mg on tumor growth stabilization in patients with progressive neuroendocrine tumors (NETs) who are not eligible to surgery or chemotherapy. Journal of Clinical Oncology 29 e14660.

Martin-Rodriguez JF, Madrazo-Atutxa A, Venegas-Moreno E, Benito-López P, Galvez MA, Cano DA, Tinahones FJ, Torres-Vela E, Soto-Moreno A \& Leal-Cerro A 2013 Neurocognitive function in acromegaly after surgical resection of GH-secreting adenoma versus naive acromegaly. PLOS ONE 8 e60041. (doi:10.1371/journal. pone.0060041)

Matta MP, Couture E, Cazals L, Vezzosi D, Bennet A \& Caron P 2008 Impaired quality of life of patients with acromegaly: control of GH/IGF-I excess improves psychological subscale appearance. European Journal of Endocrinology 158 305-310. (doi:10.1530/ EJE-07-0697)

Mazziotti G, Floriani I, Bonadonna S, Torri V, Chanson P \& Giustina A 2009 Effects of somatostatin analogs on glucose homeostasis: a metaanalysis of acromegaly studies. Journal of Clinical Endocrinology and Metabolism 94 1500-1508. (doi:10.1210/jc.2008-2332)

Mazziotti G, Porcelli T, Bogazzi F, Bugari G, Cannavo S, Colao A, Cozzi R, De ML, degli UE, Grottoli S, et al. 2011 Effects of high-dose octreotide LAR on glucose metabolism in patients with acromegaly inadequately controlled by conventional somatostatin analog therapy. European Journal of Endocrinology 164 341-347. (doi:10.1530/ EJE-10-0811)

McKeage K, Cheer S \& Wagstaff AJ 2003 Octreotide long-acting release (LAR): a review of its use in the management of acromegaly. Drugs 63 2473-2499. (doi:10.2165/00003495-200363220-00014)

Melmed S 2006 Medical progress: acromegaly. New England Journal of Medicine 355 2558-2573. (doi:10.1056/NEJMra062453)

Melmed S, Sternberg R, Cook D, Klibanski A, Chanson P, Bonert V, Vance ML, Rhew D, Kleinberg D \& Barkan A 2005 A critical analysis of pituitary tumor shrinkage during primary medical therapy in acromegaly. Journal of Clinical Endocrinology and Metabolism 90 4405-4410. (doi:10.1210/jc.2004-2466)

Melmed S, Popovic V, Bidlingmaier M, Mercado M, van der Lely AJ, Biermasz N, Bolanowski M, Coculescu M, Schopohl J, Racz K, et al. 2015 Safety and efficacy of oral octreotide in acromegaly: results of a multicenter phase III trial. Journal of Clinical Endocrinology and Metabolism 100 1699-1708. (doi:10.1210/jc.2014-4113)

Modlin IM, Latich I, Kidd M, Zikusoka M \& Eick G 2006 Therapeutic options for gastrointestinal carcinoids. Clinical Gastroenterology and Hepatology 4 526-547. (doi:10.1016/j.cgh.2005.12.008)
Moschetta A, Stolk MF, Rehfeld JF, Portincasa P, Slee PH, Koppeschaar HP, Van Erpecum KJ \& Vanberge-Henegouwen GP 2001 Severe impairment of postprandial cholecystokinin release and gall-bladder emptying and high risk of gallstone formation in acromegalic patients during Sandostatin LAR. Alimentary Pharmacology \& Therapeutics 15 181-185. (doi:10.1046/ j.1365-2036.2001.00924.x)

Murray RD \& Melmed S 2008 A critical analysis of clinically available somatostatin analog formulations for therapy of acromegaly. Journal of Clinical Endocrinology and Metabolism 93 2957-2968. (doi:10.1210/ jc.2008-0027)

Neggers SJ, Franck SE, de Rooij FW, Dallenga AH, Poublon RM, Feelders RA, Janssen JA, Buchfelder M, Hofland LJ, Jorgensen JO, et al. 2014 Long-term efficacy and safety of pegvisomant in combination with long-acting somatostatin analogues in acromegaly. Journal of Clinical Endocrinology and Metabolism 99 3644-3652. (doi:10.1210/jc.2014-2032)

Newman CB, Melmed S, Snyder PJ, Young WF, Boyajy LD, Levy R, Stewart WN, Klibanski A, Molitch ME \& Gagel RF 1995 Safety and efficacy of long-term octreotide therapy of acromegaly: results of a multicenter trial in 103 patients - a clinical research center study. Journal of Clinical Endocrinology and Metabolism $802768-2775$. (doi:10.1210/jc.80.9.2768)

Nomikos P, Buchfelder M \& Fahlbusch R 2005 The outcome of surgery in 668 patients with acromegaly using current criteria of biochemical 'cure'. European Journal of Endocrinology 152 379-387. (doi:10.1530/eje.1.01863)

Novartis Pharmaceuticals 2012 Sandostatin LAR (Octreotide Acetate) Basic Prescribing Information. East Hanover, NJ, USA: Novartis Pharmaceuticals.

Oberg K 2005 Neuroendocrine tumors of the gastrointestinal tract: recent advances in molecular genetics, diagnosis, and treatment. Current Opinion in Oncology 17 386-391. (doi:10.1097/01.cco.0000167739.56948.a9)

Oberg K, Knigge U, Kwekkeboom D \& Perren A 2012 Neuroendocrine gastro-entero-pancreatic tumors: ESMO Clinical Practice Guidelines for diagnosis, treatment and follow-up. Annals of Oncology 23 (Supplement 7) vii124-vii130. (doi:10.1093/annonc/mds295)

Ogmen B, Polat B, Cuhaci N, Aydin C, Ersoy R \& Cakir B 2015 Lanreotide-induced bradycardia and supraventricular extrasystoles. Endocrine Abstracts 35 abstract P916. (doi:10.1530/endoabs.35.p916)

Pagès P, Benali N, Saint-Laurent N, Estève J-P, Schally AV, Tkaczuk J, Vaysse N, Susini C \& Buscail L 1999 sst2 somatostatin receptor mediates cell cycle arrest and induction of p27Kip1. Evidence for the role of SHP-1. Journal of Biological Chemistry 274 15186-15193. (doi:10.1074/jbc.274.21.15186)

Patel YC 1999 Somatostatin and its receptor family. Frontiers in Neuroendocrinology 20 157-198. (doi:10.1006/frne.1999.0183)

Pavel ME, Hainsworth JD, Baudin E, Peeters M, Horsch D, Winkler RE, Klimovsky J, Lebwohl D, Jehl V, Wolin EM, et al. 2011 Everolimus plus octreotide long-acting repeatable for the treatment of advanced neuroendocrine tumours associated with carcinoid syndrome (RADIANT-2): a randomised, placebo-controlled, phase 3 study. Lancet 378 2005-2012. (doi:10.1016/S0140-6736(11)61742-X)

Petersenn S, Hu K, Maldonado M, Zhang Y, Lasher J, Bouillaud E, Wang Y, Mann K \& Unger N 2012a Tolerability and doseproportional pharmacokinetics of pasireotide administered as a single dose or two divided doses in healthy male volunteers: a single-center, open-label, ascending-dose study. Clinical Therapeutics 34 677-688. (doi:10.1016/j.clinthera.2012.01.015)

Petersenn S, Unger N, Hu K, Weisshaar B, Zhang Y, Bouillaud E, Hermosillo Resendiz K, Wang Y \& Mann K 2012b Pasireotide (SOM230), a novel multi-receptor-targeted somatostatin analogue, is well tolerated when administered as a continuous 7-day subcutaneous infusion in healthy male volunteers. Journal of Clinical Pharmacology 52 1017-1027. (doi:10.1177/0091270011408727) 
Petrossians P, Borges-Martins L, Espinoza C, Daly A, Betea D, ValdesSocin H, Stevenaert A, Chanson P \& Beckers A 2005 Gross total resection or debulking of pituitary adenomas improves hormonal control of acromegaly by somatostatin analogs. European Journal of Endocrinology 152 61-66. (doi:10.1530/eje.1.01824)

Pita-Gutierrez F, Pertega-Diaz S, Pita-Fernandez S, Pena L, Lugo G, Sangiao-Alvarellos S \& Cordido F 2013 Place of preoperative treatment of acromegaly with somatostatin analog on surgical outcome: a systematic review and meta-analysis. PLOS ONE $\mathbf{8}$ e61523. (doi:10.1371/journal.pone.0061523)

Plöckinger U, Albrecht S, Mawrin C, Saeger W, Buchfelder M, Petersenn S \& Schulz S 2008 Selective loss of somatostatin receptor 2 in octreotide-resistant growth hormone-secreting adenomas. Journal of Clinical Endocrinology and Metabolism 93 1203-1210. (doi:10.1210/ jc.2007-1986)

Pouget E, Fay N, Dujardin E, Jamin N, Berthault P, Perrin L, Pandit A, Rose T, Valéry C, Thomas D, et al. 2010 Elucidation of the self-assembly pathway of lanreotide octapeptide into beta-sheet nanotubes: role of two stable intermediates. Journal of the American Chemical Society 132 4230-4241. (doi:10.1021/ja9088023)

Powlson AS \& Gurnell M 2016 Cardiovascular disease and sleepdisordered breathing in acromegaly. Neuroendocrinology 103 75-85. (doi:10.1159/000438903)

Rajasoorya C, Holdaway IM, Wrightson P, Scott DJ \& Ibbertson HK 1994 Determinants of clinical outcome and survival in acromegaly. Clinical Endocrinology 41 95-102. (doi:10.1111/j.1365-2265.1994.tb03789.x)

Ramirez C, Vargas G, Gonzalez B, Grossman A, Rabago J, Sosa E, Espinosa-de-los-Monteros AL \& Mercado M 2012 Discontinuation of octreotide LAR after long-term, succesful treatment of patients with acromegaly: is it worth trying? European Journal of Endocrinology 166 21-26. (doi:10.1530/EJE-11-0738)

Rinke A, Müller H-H, Schade-Brittinger C, Klose K-J, Barth P, Wied M, Mayer C, Aminossadati B, Pape U-F, Bläker M, et al. 2009 Placebo-controlled, double-blind, prospective, randomized study of the effect of octreotide LAR in the control of tumor growth in patients with metastatic neuroendocrine midgut tumors: a report from the PROMID study group. Journal of Clinical Oncology $\mathbf{2 7}$ 4656-4663. (doi:10.1200/JCO.2009.22.8510)

Ritvonen E, Loyttyniemi E, Jaatinen P, Ebeling T, Moilanen L, Nuutila P, Kauppinen-Makelin R \& Schalin-Jantti C 2015 Mortality in acromegaly: a 20-year follow-up study. Endocrine-Related Cancer 23 469-480. (doi:10.1530/ERC-16-0106)

Robertson RG, Geiger WJ \& Davis NB 2006 Carcinoid tumors. American Family Physician 74 429-434.

Rokkas T, Pistiolas D, Sechopoulos P, Margantinis G \& Koukoulis G 2008 Risk of colorectal neoplasm in patients with acromegaly: a meta-analysis. World Journal of Gastroenterology 14 3484-3489. (doi:10.3748/wjg.14.3484)

Romer A, Seiler D, Marincek N, Brunner P, Koller MT, Ng QK, Maecke HR, Muller-Brand J, Rochlitz C, Briel M, et al. 2014 Somatostatin-based radiopeptide therapy with [177Lu-DOTA]-TOC versus [90Y-DOTA]-TOC in neuroendocrine tumours. European Journal of Nuclear Medicine and Molecular Imaging 41 214-222. (doi:10.1007/s00259-013-2559-8)

Ronchi C, Epaminonda P, Cappiello V, Beck-Peccoz P \& Arosio M 2002 Effects of two different somatostatin analogs on glucose tolerance in acromegaly. Journal of Endocrinological Investigation 25 502-507. (doi:10.1007/BF03345491)

Rowles SV, Prieto L, Badia X, Shalet SM, Webb SM \& Trainer PJ 2005 Quality of life (QOL) in patients with acromegaly is severely impaired: use of a novel measure of QOL: acromegaly quality of life questionnaire. Journal of Clinical Endocrinology and Metabolism 90 3337-3341. (doi:10.1210/jc.2004-1565)

Rubin J, Ajani J, Schirmer W, Venook AP, Bukowski R, Pommier R, Saltz L, Dandona P \& Anthony L 1999 Octreotide acetate long-acting formulation versus open-label subcutaneous octreotide acetate in malignant carcinoid syndrome. Journal of Clinical Oncology $\mathbf{1 7}$ 600-606.

Sandret L, Maison P \& Chanson P 2011 Place of cabergoline in acromegaly: a meta-analysis. Journal of Clinical Endocrinology and Metabolism 96 1327-1335. (doi:10.1210/jc.2010-2443)

Sanno N, Teramoto A, Osamura RY, Horvath E, Kovacs K, Lloyd RV \& Scheithauer BW 2003 Pathology of pituitary tumors. Neurosurgical Clinics of North America 14 25-39. (doi:10.1016/S1042-3680(02)00035-9)

Schmid HA 2008 Pasireotide (SOM230): development, mechanism of action and potential applications. Molecular and Cellular Endocrinology 286 69-74. (doi:10.1016/j.mce.2007.09.006)

Schmid HA \& Brueggen J 2012 Effects of somatostatin analogues on glucose homeostasis in rats. Journal of Endocrinology 212 49-60. (doi:10.1530/JOE-11-0224)

Schmid HA \& Schoeffter P 2004 Functional activity of the multiligand analog SOM230 at human recombinant somatostatin receptor subtypes supports its usefulness in neuroendocrine tumors. Neuroendocrinology 80 (Supplement 1) 47-50. (doi:10.1159/000080741)

Schreiber I, Buchfelder M, Droste M, Forssmann K, Mann K, Saller B \& Strasburger CJ 2007 Treatment of acromegaly with the GH receptor antagonist pegvisomant in clinical practice: safety and efficacy evaluation from the German Pegvisomant Observational Study. European Journal of Endocrinology 156 75-82. (doi:10.1530/eje.1.02312)

Shen M, Shou X, Wang Y, Zhang Z, Wu J, Mao Y, Li S \& Zhao Y 2010 Effect of presurgical long-acting octreotide treatment in acromegaly patients with invasive pituitary macroadenomas: a prospective randomized study. Endocrine Journal 57 1035-1044. (doi:10.1507/endocrj.K10E-203)

Sheppard MC 2003 Primary medical therapy for acromegaly. Clinical Endocrinology 58 387-399. (doi:10.1046/j.1365-2265.2003.01734.x)

Sherlock M, Ayuk J, Tomlinson JW, Toogood AA, ragon-Alonso A, Sheppard MC, Bates AS \& Stewart PM 2010 Mortality in patients with pituitary disease. Endocrine Reviews 31 301-342. (doi:10.1210/ er.2009-0033)

Shimon I, Cohen ZR, Ram Z \& Hadani M 2001 Transsphenoidal surgery for acromegaly: endocrinological follow-up of 98 patients. Neurosurgery 48 1239-1243. (doi:10.1227/00006123-200106000-00008)

Sideris L, Dube P \& Rinke A 2012 Antitumor effects of somatostatin analogs in neuroendocrine tumors. Oncologist 17 747-755. (doi:10.1634/theoncologist.2011-0458)

Sievers C, Dimopoulou C, Pfister H, Lieb R, Steffin B, Roemmler J, Schopohl J, Mueller M, Schneider HJ, Ising M, et al. 2009a Prevalence of mental disorders in acromegaly: a cross-sectional study in 81 acromegalic patients. Clinical Endocrinology 71 691-701. (doi:10.1111/j.1365-2265.2009.03555.x)

Sievers C, Ising M, Pfister H, Dimopoulou C, Schneider HJ, Roemmler J, Schopohl J \& Stalla GK $2009 b$ Personality in patients with pituitary adenomas is characterized by increased anxiety-related traits: comparison of 70 acromegalic patients with patients with nonfunctioning pituitary adenomas and age- and gender-matched controls. European Journal of Endocrinology 160 367-373. (doi:10.1530/EJE-08-0896)

Solcia E, Kloppel G \& Sobin HL in collaboration with nine pathologists from four countries 2000 World Health Organization international histological classification of tumours: histological typing of endocrine tumours: second edition. Clinical Endocrinology 53259. (doi:10.1046/j.1365-2265.2000.01073.x)

Stevenaert A \& Beckers A 1996 Presurgical octreotide: treatment in acromegaly. Metabolism 45 72-74. (doi:10.1016/S0026-0495(96)90088-8)

Strosberg JR, Yao JC, Bajetta E, Aout M, Bakker B, Hainsworth JD, Ruszniewski PB, Van CE, Oberg K \& Pavel ME 2015 Efficacy of octreotide long-acting repeatable in neuroendocrine tumors: RADIANT-2 placebo arm post hoc analysis. Endocrine-Related Cancer 22 933-940. (doi:10.1530/ERC-15-0314)

Strosberg JR, Wolin EM, Chasen B, Kulke MH, Bushnell DL, Caplin ME, Baum RP, Kunz PL, Hobday TJ, Hendifar AE, et al. 2016 
NETTER-1 phase III: progression-free survival, radiographic response, and preliminary overall survival results in patients with midgut neuroendocrine tumors treated with 177-Lu-dotatate. Journal of Clinical Oncology 34 (Supplement 4S) abstract 194. (doi:10.1200/ JCO.2015.64.1514)

Swearingen B, Barker FG, Katznelson L, Biller BM, Grinspoon S, Klibanski A, Moayeri N, Black PM \& Zervas NT 1998 Long-term mortality after transsphenoidal surgery and adjunctive therapy for acromegaly. Journal of Clinical Endocrinology and Metabolism $\mathbf{8 3}$ 3419-3426. (doi:10.1210/jc.83.10.3419)

T'Sjoen G, Bex M, Maiter D, Velkeniers B \& Abs R 2007 Health-related quality of life in acromegalic subjects: data from AcroBel, the Belgian registry on acromegaly. European Journal of Endocrinology $\mathbf{1 5 7}$ 411-417. (doi:10.1530/eje-07-0356)

Taboada GF, Luque RM, Neto LV, Machado Ede O, Sbaffi BC, Domingues RC, Marcondes JB, Chimelli LM, Fontes R, Niemeyer P, et al. 2008 Quantitative analysis of somatostatin receptor subtypes (1-5) gene expression levels in somatotropinomas and correlation to in vivo hormonal and tumor volume responses to treatment with octreotide LAR. European Journal of Endocrinology 158 295-303. (doi:10.1530/EJE-07-0562)

Tiberg F \& Johnsson M 2011 Drug delivery applications of nonlamellar liquid crystalline phases and nanoparticles. Journal of Drug Delivery Science and Technology 21 101-109. (doi:10.1016/S17732247(11)50009-7)

Tiberg F, Johnsson M, Jankunec M \& Barauskas J 2012a Phase behavior, functions, and medical applications of soy phosphatidylcholine and diglyceride lipid compositions. Chemistry Letters 41 1090-1092. (doi:10.1246/cl.2012.1090)

Tiberg F, Johnsson M, Nistor C \& Joabsson F 2012b Self-assembling lipid formulations. In Long-Acting Injections and Implants, pp 315-334. Eds JC Wright \& DJ Burgess. New York, NY, USA: Springer.

Tiberg F, Roberts J, Cervin C, Johnsson M, Sarp S, Tripathi AP \& Linden M 2015 Octreotide sc depot provides sustained octreotide bioavailability and similar IGF-1 suppression to octreotide LAR in healthy volunteers. British Journal of Clinical Pharmacology $\mathbf{8 0}$ 460-472. (doi:10.1111/bcp.12698)

Trainer PJ, Drake WM, Katznelson L, Freda PU, Herman-Bonert V, van der Lely AJ, Dimaraki EV, Stewart PM, Friend KE, Vance ML, et al. 2000 Treatment of acromegaly with the growth hormone-receptor antagonist pegvisomant. New England Journal of Medicine $\mathbf{3 4 2}$ 1171-1177. (doi:10.1056/NEJM200004203421604)

Trainer PJ, Ezzat S, D'Souza GA, Layton G \& Strasburger CJ 2009 A randomized, controlled, multicentre trial comparing pegvisomant alone with combination therapy of pegvisomant and long-acting octreotide in patients with acromegaly. Clinical Endocrinology $\mathbf{7 1}$ 549-557. (doi:10.1111/j.1365-2265.2009.03620.x)

Trendle MC, Moertel CG \& Kvols LK 1997 Incidence and morbidity of cholelithiasis in patients receiving chronic octreotide for metastatic carcinoid and malignant islet cell tumors. Cancer 79 830-834. (doi:10.1002/(SICI)1097-0142(19970215)79:4<830::AIDCNCR20>3.0.CO;2-\#)

Trepp R, Stettler C, Zwahlen M, Seiler R, Diem P \& Christ ER 2005 Treatment outcomes and mortality of 94 patients with acromegaly. Acta Neurochirurgica 147 243-251. (doi:10.1007/s00701-004-0466-2)

Turner HE, Thornton-Jones VA \& Wass JA 2004 Systematic doseextension of octreotide LAR: the importance of individual tailoring of treatment in patients with acromegaly. Clinical Endocrinology $\mathbf{6 1}$ 224-231. (doi:10.1111/j.1365-2265.2004.02084.x) van der Klaauw AA, Kars M, Biermasz NR, Roelfsema F, Dekkers OM, Corssmit EP, van Aken MO, Havekes B, Pereira AM, Pijl H, et al. 2008 Disease-specific impairments in quality of life during long-term follow-up of patients with different pituitary adenomas. Clinical Endocrinology 69 775-784. (doi:10.1111/j.1365-2265.2008.03288.x)

van der Lely AJ, Hutson RK, Trainer PJ, Besser GM, Barkan AL, Katznelson L, Klibanski A, Herman-Bonert V, Melmed S, Vance ML, et al. 2001a Long-term treatment of acromegaly with pegvisomant, a growth hormone receptor antagonist. Lancet 358 1754-1759. (doi:10.1016/s0140-6736(01)06844-1)

van der Lely AJ, Muller A, Janssen JA, Davis RJ, Zib KA, Scarlett JA \& Lamberts SW $2001 b$ Control of tumor size and disease activity during cotreatment with octreotide and the growth hormone receptor antagonist pegvisomant in an acromegalic patient. Journal of Clinical Endocrinology and Metabolism 86 478-481. (doi:10.1210/ jc.86.2.478)

van der Lely AJ, Biller BM, Brue T, Buchfelder M, Ghigo E, Gomez R, Hey-Hadavi J, Lundgren F, Rajicic N, Strasburger CJ, et al. 2012 Longterm safety of pegvisomant in patients with acromegaly: comprehensive review of 1288 subjects in ACROSTUDY. Journal of Clinical Endocrinology and Metabolism 97 1589-1597. (doi:10.1210/ jc.2011-2508)

Vance ML \& Harris AG 1991 Long-term treatment of 189 acromegalic patients with the somatostatin analog octreotide. Results of the International Multicenter Acromegaly Study Group. Archives of Internal Medicine 151 1573-1578. (doi:10.1001/archinte.1991.00400080073013)

Villard L, Romer A, Marincek N, Brunner P, Koller MT, Schindler C, Ng QK, Macke HR, Muller-Brand J, Rochlitz C, et al. 2012 Cohort study of somatostatin-based radiopeptide therapy with [(90)YDOTA]-TOC versus [(90)Y-DOTA]-TOC plus [(177)Lu-DOTA]-TOC in neuroendocrine cancers. Journal of Clinical Oncology 30 1100-1106. (doi:10.1200/JCO.2011.37.2151)

Webb SM 2006 Quality of life in acromegaly. Neuroendocrinology $\mathbf{8 3}$ 224-229. (doi:10.1159/000095532)

Wildemberg LE, Neto LV, Costa DF, Nasciuti LE, Takiya CM, Alves LM, Rebora A, Minuto F, Ferone D \& Gadelha MR 2013 Low somatostatin receptor subtype 2 , but not dopamine receptor subtype 2 expression predicts the lack of biochemical response of somatotropinomas to treatment with somatostatin analogs. Journal of Endocrinological Investigation 36 38-43.

Wolin EM, Jarzab B, Eriksson B, Walter T, Toumpanakis C, Morse MA, Tomassetti P, Weber MM, Fogelman DR, Ramage J, et al. 2015 Phase III study of pasireotide long-acting release in patients with metastatic neuroendocrine tumors and carcinoid symptoms refractory to available somatostatin analogues. Drug, Design, Development and Therapy 9 5075-5086. (doi:10.2147/DDDT.S84177)

Yao JC, Hassan M, Phan A, Dagohoy C, Leary C, Mares JE, Abdalla EK, Fleming JB, Vauthey JN, Rashid A, et al. 2008 One hundred years after 'carcinoid': epidemiology of and prognostic factors for neuroendocrine tumors in 35,825 cases in the United States. Journal of Clinical Oncology 26 3063-3072. (doi:10.1200/JCO.2007.15.4377)

Yao JC, Shah MH, Ito T, Bohas CL, Wolin EM, Van CE, Hobday TJ, Okusaka T, Capdevila J, de Vries EG, et al. 2011 Everolimus for advanced pancreatic neuroendocrine tumors. New England Journal of Medicine 364 514-523. (doi:10.1056/NEJMoa1009290)

Yao JC, Lagunes DR \& Kulke MH 2013 Targeted therapies in neuroendocrine tumors (NET): clinical trial challenges and lessons learned. Oncologist 18 525-532. (doi:10.1634/ theoncologist.2012-0434)

Received in final form 11 August 2016

Accepted 3 October 2016

Accepted Preprint published online 3 October 2016
() 2016 Society for Endocrinology Printed in Great Britain
Published by Bioscientifica Ltd. 